\title{
Prognostic effect of age on survival of patients with stage I adenocarcinoma of the lung
}

\author{
Jeong-Seon Ryu' ${ }^{1}$, Chang-Min $\mathrm{Choi}^{2}$, Seok-Chul Yang ${ }^{3}$, Sang-Yun Song ${ }^{4}$, \\ Young-June Jeon ${ }^{5}$, Tae-Won Jang ${ }^{6}$, Do-Jin $\mathrm{Kim}^{7}$, Seung Hun Jang ${ }^{8}$, \\ Sei-Hoon Yang ${ }^{9}$, Min-Ki Lee ${ }^{10}$, Kwan-Ho Lee ${ }^{11}$, Hyang-Jeong Jo ${ }^{9}$, \\ Se-Jin Jang ${ }^{2}$, Young-Tae Kim³, Jae-Hwa Cho', Yoo-Duk Choi ${ }^{12}$, \\ Hae-Seong Nam ${ }^{1}$, Hyun-Jung Kim¹, and Young Ju Suh ${ }^{13}$
}

${ }^{1}$ Center for Lung Cancer and Pulmonary Division, Department of Internal Medicine, Inha University Hospital, Inchon; ${ }^{2}$ Department of Pulmonary and Critical Care Medicine, Asan Medical Center, College of Medicine, University of Ulsan, Seoul; ${ }^{3}$ Division of Pulmonary and Critical Care Medicine, Department of Internal Medicine, Seoul National University College of Medicine, Seoul; ' ${ }^{4}$ Department of Thoracic and Cardiovascular Surgery, Chonnam National University Hwasun Hospital, Hwasungun; ${ }^{5}$ Department of Internal Medicine, School of Medicine, Keimyung University, Daegu; ${ }^{6}$ Department of Internal Medicine, College of Medicine, Kosin University, Busan; ${ }^{7}$ Division of Respiratory and Allergy Medicine, Soonchunhyang University Hospital, College of Medicine, Bucheon; ${ }^{8}$ Division of Pulmonary, Allergy \& Critical Care Medicine, Hallym University Sacred Heart Hospital, Hallym University College of Medicine, Anyang; ${ }^{9}$ Department of Internal Medicine, Wonkwang University Hospital, Iksan; ${ }^{10}$ Department of Internal Medicine, School of Medicine, Pusan National University, Busan; ${ }^{11}$ Department of Internal Medicine, School of Medicine, Yeungnam University, Daegu; ${ }^{12}$ Department of Pathology, Chonnam National University Hwasun Hospital, Hwasun-gun; ${ }^{13}$ Clinical Research Institute, School of Medicine, Inha University, Incheon, Korea

ABSTRACT

Aims and background. It is still unclear whether age is an independent prognostic factor in patients with stage I NSCLC.

Methods. Five hundred and sixty-nine patients with stage I adenocarinoma who underwent surgical resection as first treatment were included. The effect on overall survival of age, gender, smoking habits, Charlson comorbidity index score (CCIS), type of surgery, tumor size and lymphatic or blood vessel invasion was analyzed.

Results. When the patients were divided into four groups according to quartiles of age, distributions of gender, smoking habit, CCIS, histology, blood vessel invasion and adjuvant chemotherapy were significantly different among the four groups. Age, gender, smoking habit, CCIS, tumor size and lymphatic and blood vessel invasion were significantly associated with overall survival of the patients in Kaplan-Meier analysis (logrank, $P<0.001, P<0.001, P=0.029, P<0.001, P=0.001, P=0.001$ and $P=$ 0.007 , respectively). Moreover, the highest quartile of age (over 68 years old) was a prominent determinant for a worse prognosis after adjustment for the confounding variables using a Cox proportional hazard model (adjusted hazard ratio $=2.735,95 \%$ confidence interval $=1.623-4.608, P<0.001)$.

Conclusions. The findings suggest that age is an important determinant of overall survival in patients with stage I adenocarcinoma. Therefore, age should be considered in classifying the patients into groups of higher or lower risk for death as well as in designing clinical trials.

\section{Introduction}

Lung cancer is the most common cause of cancer-related death in many countries, but the 5-year survival of patients with non-small cell lung cancer (NSCLC) has been slowly improving and is now $16 \%^{1}$. In patients with stage I NSCLC, 5 -year survival is still disappointing at $58-73 \%^{2}$, and adjuvant chemotherapy seems even to be harmful by lung ad-
Key words: age, adenocarcinoma, non-small cell lung cancer, survival.

Acknowledgments: The study was supported by grants of the Korea Healthcare technology R\&D Project, Ministry for Health, Welfare \& Family Affairs, Republic of Korea (A084452) and Inha University.

Disclosures and Conflict of Interest None.

Correspondence to: Jeong Seon Ryu, MD, PhD, Professor, Pulmonary Division, School of Medicine, Inha University, Director, Center for Lung Cancer, Inha University Hospital, 7-206, 3-Ga, Shinheung Dong, Jung Gu, Incheon, 400-103, South Korea. Tel 82-32-890-3738; fax 82-32-882-6578; e-mail jsryu@inha.ac.kr accepted May 13, 2011. 
juvant cisplatin evaluation meta-analysis ${ }^{3}$. The recent increase in incidence of stage I lung cancer, especially adenocarcinoma, has been suggested to be attributable to the effects of screening for lung cancer, increased awareness of lung cancer, and ethnic differences or environmental factors, but its cause remains largely unclear.

In addition to the development of prognostic biomarkers, another issue in terms of identifying biologic differences or choosing the subgroup needing adjuvant treatment is clinical factors affecting prognosis at this stage of disease. Compared with older patients with lung cancer, younger patients may be less likely to be exposed to cigarette smoke or have significant comorbidities and more likely to have different tumor biology ${ }^{4-6}$. Therefore, we thought age was a potentially important prognostic factor. However, studies investigating whether age has a prognostic value have shown inconsistent results ${ }^{7,8}$. In numerous previous studies, the prognostic values of gender, smoking, comorbidity, histology, tumor size and lymphatic or blood vessel invasion have been identified in stage I NSCLC patients ${ }^{5-7,9-16}$, but in most series the prognostic relevance of all of these clinical variables was not verified. Moreover, some studies consisted of small numbers of patients or varieties of tumor histology, stage, or treatment given.

The present study was therefore limited to patients with pathologically staged T1-2, N0, M0 adenocarcinoma to reduce confounding effects on survival analysis possibly attributable to differences in stage or histology, and we evaluated the prognostic relevance of these clinical variables.

\section{Methods}

\section{Patients}

Of patients retrospectively enrolled in a study on the development of biomarkers for stage I NSCLC using tissue microarrays, those with adenocarcinoma of the lung were selected for inclusion in the study. Patients underwent complete surgical resection between January 1997 and December 2005 according to the recommendations of the American Joint Committee on Cancer, sixth edition ${ }^{17}$. After patients who received preoperative chemotherapy, radiation therapy or target agents or who had previous lung cancer were excluded, 569 patients were included in the study. Information regarding smoking habits, Charlson comorbidity index score (CCIS), type of surgery, tumor size, type of histology (adenocarcinoma or pure bronchioloalveolar carcinoma), lymphatic vessel invasion, blood vessel invasion in the pathologic specimen, and adjuvant treatment was collected using uniform data sheets from 11 university hospitals in Korea. The study was approved by the Institutional Review Boards of each hospital. Informed consent of patients was waived.

\section{Survival measurements}

The end point of the study was overall survival estimated from the date of surgery. Dates of death were obtained mainly from reviewing medical records. To increase the quality of information on survival status in patients lost to follow-up, information about survival was obtained by contacting the patients or their relatives by phone or mail, or from the Ministry of Public Administration and Security, South Korea. Of the 569 patients, 178 (31.8\%) were dead and 391 alive.

\section{Statistical analysis}

The patients were divided into four groups according to quartiles of age. The cutoff values of the $25^{\text {th }}, 50^{\text {th }}$ and $75^{\text {th }}$ percentile of age were 55, 62 and 68 years old, respectively. The $\chi^{2}$ test and Fisher's exact test for heterogeneity were used to compare the distributions of the clinical variables between the groups. The effects of each clinical variable as well as the age groups on overall survival rates were estimated using the Kaplan-Meier method. The difference in overall survival curves among subgroups of each clinical variable was tested using the logrank test. The hazard ratio (HR), adjusted for potential confounders, and the $95 \%$ confidence interval (CI) were estimated using the Cox proportional hazards model. Statistical significance was assumed at the two-sided 0.05 level. All statistical analyses were performed using the SAS software package (v. 9.1.3, SAS institute, Cary, NC, USA).

\section{Results}

\section{Characteristics of patients}

Table 1 provides the demographic and clinical characteristics of the patients by age group. Median age was 62.0 years (range, 21-82). The patients consisted of 312 men $(22.4 \%$ never smokers, $77.6 \%$ smokers $)$ and 257 women (90.2\% never smokers, $9.8 \%$ smokers). Pure bronchioloalveolar carcinoma was more commonly seen in women than in men $(33.3 \%$ vs $21.2 \%, P=0.001)$ (data not shown). The distributions of gender, smoking habit, CCIS, histology, blood vessel invasion and adjuvant chemotherapy were shown to be significantly different among the four age groups $(P<0.05)$. The highest quartile of age (eldest group) showed a tendency of being men, ever smoker, higher CCIS, adenocarcinoma, and low probability of having blood vessel invasion or receiving adjuvant chemotherapy.

\section{Comparison of survival rates for clinical variables}

The 5-year survival of the 569 patients was $73 \%$. Median survival time of the patients had not been reached at this writing (data not shown). Overall survival rates were significantly different among the four age groups (logrank $P<0.001$, Figure 1). 
Table 1 - Baseline characteristics of patients with pathologic stage I adenocarcinoma according to quartiles of age

\begin{tabular}{|c|c|c|c|c|c|c|c|c|c|c|c|c|}
\hline \multirow[t]{2}{*}{ Variable } & & \multirow[b]{2}{*}{ No. } & \multirow[b]{2}{*}{$\%$} & \multicolumn{2}{|c|}{$\begin{array}{c}\text { Quartile } 1 \\
(<55 \mathrm{yr})\end{array}$} & \multicolumn{2}{|c|}{$\begin{array}{l}\text { Quartile } 2 \\
\text { (55-61 yr) }\end{array}$} & \multicolumn{2}{|c|}{$\begin{array}{l}\text { Quartile } 3 \\
(62-67 \mathrm{yr})\end{array}$} & \multicolumn{2}{|c|}{$\begin{array}{l}\text { Quartile } 4 \\
\text { ( } \geq 68 \mathrm{yr})\end{array}$} & \multirow[t]{2}{*}{$P^{a}$} \\
\hline & & & & No. & $\%$ & No. & $\%$ & No. & $\%$ & No. & $\%$ & \\
\hline Gender & $\begin{array}{l}\text { Men } \\
\text { Women }\end{array}$ & $\begin{array}{l}312 \\
257\end{array}$ & $\begin{array}{l}54.8 \\
45.2\end{array}$ & $\begin{array}{l}61 \\
74\end{array}$ & $\begin{array}{l}19.6 \\
28.8\end{array}$ & $\begin{array}{l}66 \\
58\end{array}$ & $\begin{array}{l}21.2 \\
22.6\end{array}$ & $\begin{array}{l}79 \\
64\end{array}$ & $\begin{array}{l}25.3 \\
24.9\end{array}$ & $\begin{array}{r}106 \\
61\end{array}$ & $\begin{array}{l}34.0 \\
23.7\end{array}$ & 0.017 \\
\hline Smoking habit & $\begin{array}{l}\text { Never } \\
\text { Ever }\end{array}$ & $\begin{array}{l}290 \\
260\end{array}$ & $\begin{array}{l}32.7 \\
47.3\end{array}$ & $\begin{array}{l}75 \\
56\end{array}$ & $\begin{array}{l}25.9 \\
21.5\end{array}$ & $\begin{array}{l}73 \\
47\end{array}$ & $\begin{array}{l}25.2 \\
18.1\end{array}$ & $\begin{array}{l}76 \\
63\end{array}$ & $\begin{array}{l}26.2 \\
24.2\end{array}$ & $\begin{array}{l}66 \\
94\end{array}$ & $\begin{array}{l}22.8 \\
36.2\end{array}$ & 0.005 \\
\hline CCIS & $\begin{array}{l}0 \\
1 \\
\geq 2\end{array}$ & $\begin{array}{l}226 \\
149 \\
149\end{array}$ & $\begin{array}{l}43.1 \\
28.4 \\
28.4\end{array}$ & $\begin{array}{l}71 \\
27 \\
20\end{array}$ & $\begin{array}{l}31.4 \\
18.1 \\
13.4\end{array}$ & $\begin{array}{l}55 \\
32 \\
32\end{array}$ & $\begin{array}{l}24.3 \\
21.5 \\
21.5\end{array}$ & $\begin{array}{l}50 \\
33 \\
50\end{array}$ & $\begin{array}{l}22.1 \\
22.1 \\
33.6\end{array}$ & $\begin{array}{l}50 \\
57 \\
47\end{array}$ & $\begin{array}{l}22.1 \\
38.3 \\
31.5\end{array}$ & $<0.001$ \\
\hline Histology & $\begin{array}{l}\text { ADC } \\
\text { BAC }\end{array}$ & $\begin{array}{l}418 \\
151\end{array}$ & $\begin{array}{l}73.5 \\
26.5\end{array}$ & $\begin{array}{l}91 \\
44\end{array}$ & $\begin{array}{l}21.8 \\
29.1\end{array}$ & $\begin{array}{l}82 \\
42\end{array}$ & $\begin{array}{l}19.6 \\
27.8\end{array}$ & $\begin{array}{r}113 \\
30\end{array}$ & $\begin{array}{l}27.0 \\
19.9\end{array}$ & $\begin{array}{r}132 \\
35\end{array}$ & $\begin{array}{l}31.6 \\
23.2\end{array}$ & 0.012 \\
\hline Tumor size, $\mathrm{cm}$ & $\begin{array}{l}\leq 2 \\
>2 \text { to } \leq 3 \\
>3 \text { to } \leq 5 \\
>5\end{array}$ & $\begin{array}{r}137 \\
198 \\
168 \\
61\end{array}$ & $\begin{array}{l}24.3 \\
35.1 \\
29.8 \\
10.8\end{array}$ & $\begin{array}{l}40 \\
43 \\
33 \\
16\end{array}$ & $\begin{array}{l}29.2 \\
21.7 \\
19.6 \\
26.2\end{array}$ & $\begin{array}{l}26 \\
43 \\
39 \\
16\end{array}$ & $\begin{array}{l}19.0 \\
21.7 \\
23.2 \\
26.2\end{array}$ & $\begin{array}{l}33 \\
56 \\
37 \\
16\end{array}$ & $\begin{array}{l}24.1 \\
28.3 \\
22.0 \\
26.2\end{array}$ & $\begin{array}{l}38 \\
56 \\
59 \\
13\end{array}$ & $\begin{array}{l}27.7 \\
28.3 \\
35.1 \\
21.3\end{array}$ & 0.387 \\
\hline Type of surgery & $\begin{array}{l}\text { Segmentectomy } \\
\text { Lobectomy } \\
\text { Bilobectomy } \\
\text { Pneumonectomy }\end{array}$ & $\begin{array}{r}6 \\
518 \\
28 \\
17\end{array}$ & $\begin{array}{r}1.1 \\
91.0 \\
4.9 \\
3.0\end{array}$ & $\begin{array}{r}1 \\
125 \\
6 \\
3\end{array}$ & $\begin{array}{l}16.7 \\
24.1 \\
21.4 \\
17.6\end{array}$ & $\begin{array}{r}1 \\
113 \\
4 \\
6\end{array}$ & $\begin{array}{l}16.7 \\
21.8 \\
14.3 \\
35.3\end{array}$ & $\begin{array}{r}2 \\
125 \\
10 \\
6\end{array}$ & $\begin{array}{l}33.3 \\
24.1 \\
35.7 \\
35.3\end{array}$ & $\begin{array}{r}2 \\
155 \\
8 \\
2\end{array}$ & $\begin{array}{l}33.3 \\
29.9 \\
28.6 \\
11.8\end{array}$ & 0.647 \\
\hline $\begin{array}{l}\text { Lymphatic vessel } \\
\text { invasion }\end{array}$ & $\begin{array}{l}\text { Yes } \\
\text { No }\end{array}$ & $\begin{array}{r}66 \\
447\end{array}$ & $\begin{array}{l}12.9 \\
87.1\end{array}$ & $\begin{array}{l}22 \\
97\end{array}$ & $\begin{array}{l}33.3 \\
21.7\end{array}$ & $\begin{array}{r}8 \\
101\end{array}$ & $\begin{array}{l}12.1 \\
22.6\end{array}$ & $\begin{array}{r}19 \\
111\end{array}$ & $\begin{array}{l}28.8 \\
24.8\end{array}$ & $\begin{array}{r}17 \\
138\end{array}$ & $\begin{array}{l}25.8 \\
30.9\end{array}$ & 0.066 \\
\hline $\begin{array}{l}\text { Blood vessel } \\
\text { invasion }\end{array}$ & $\begin{array}{l}\text { Yes } \\
\text { No }\end{array}$ & $\begin{array}{r}67 \\
413\end{array}$ & $\begin{array}{l}14.0 \\
86.0\end{array}$ & $\begin{array}{l}24 \\
85\end{array}$ & $\begin{array}{l}35.8 \\
24.6\end{array}$ & $\begin{array}{l}10 \\
95\end{array}$ & $\begin{array}{l}14.9 \\
23.0\end{array}$ & $\begin{array}{r}16 \\
105\end{array}$ & $\begin{array}{l}23.9 \\
25.4\end{array}$ & $\begin{array}{r}17 \\
128\end{array}$ & $\begin{array}{l}25.4 \\
31.0\end{array}$ & 0.041 \\
\hline $\begin{array}{l}\text { Adjuvant } \\
\text { chemotherapy }\end{array}$ & $\begin{array}{l}\text { Yes } \\
\text { No }\end{array}$ & $\begin{array}{l}100 \\
467\end{array}$ & $\begin{array}{l}17.6 \\
82.4\end{array}$ & $\begin{array}{r}30 \\
104\end{array}$ & $\begin{array}{l}30.0 \\
22.3\end{array}$ & $\begin{array}{l}33 \\
91\end{array}$ & $\begin{array}{l}33.0 \\
19.5\end{array}$ & $\begin{array}{r}23 \\
120\end{array}$ & $\begin{array}{l}23.0 \\
25.7\end{array}$ & $\begin{array}{r}14 \\
152\end{array}$ & $\begin{array}{l}14.0 \\
32.5\end{array}$ & $<0.001$ \\
\hline
\end{tabular}

ap to test any difference across the quartiles of age using the $\chi^{2}$ test or Fisher's exact test as appropriate.

CCIS, Charlson comorbidity index score; ADC, adenocarcinoma; BAC, bronchioloalveolar carcinoma.

In proportion as the quartiles increase from low to high, overall survival showed a tendency of being shorter. Overall survival curves among the subgroups of gender, smoking habit, CCIS, tumor size, lymphatic or blood vessel invasion were significantly different (Figure 2). Pure bronchioloalveolar carcinoma showed bet-

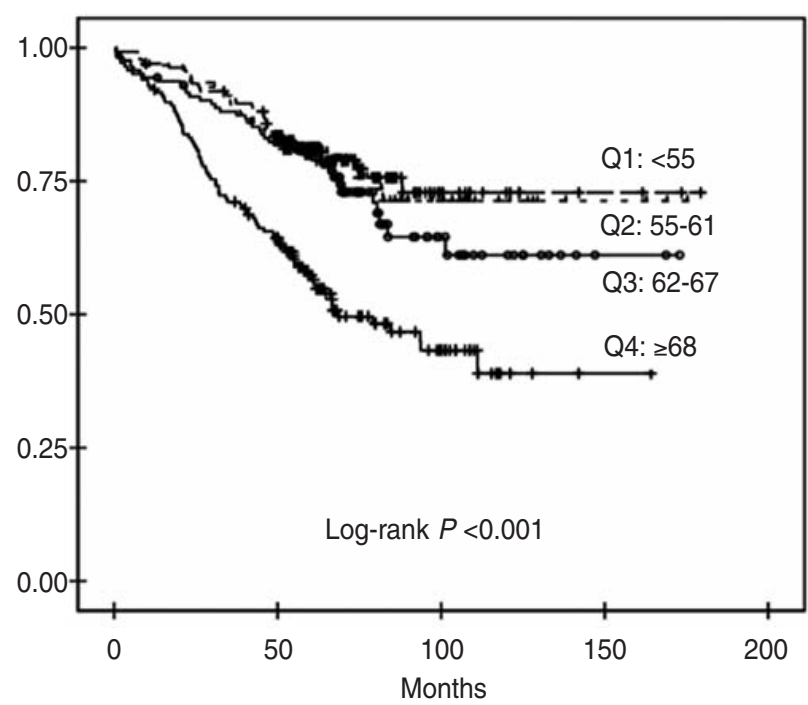

Figure 1 - Kaplan-Meier survival estimates for overall survival of 569 patients with pathologic stage I adenocarcinoma by age groups. ter survival rate than adenocarcinoma, but the difference was not significant (logrank $P=0.056$ ).

\section{Adjusted hazards ratios being affected by risk factors}

The risk of death in the group of the highest quartile of age ( $\geq 68$ years old) was significantly increased compared to that of the lowest quartile of age $(<55$ years old) after adjustment for gender, CCIS, smoking habit, type of histology, tumor size, lymphatic or blood vessel invasion and adjuvant chemotherapy (adjusted $\mathrm{HR}=2.735$; 95\% CI, 1.623-4.608; $P<0.001$ ) (Table 2). In addition, the risk for death was significantly higher for the largest ( $>5$ $\mathrm{cm}$ ) tumor (adjusted HR = 2.813; 95\% CI, 1.531-5.168; $P$ $=0.001)$. Other clinical variables including gender, smoking habit, CCIS, type of histology lymphatic or blood vessel invasion and adjuvant chemotherapy were not associated with risk of death after the adjustment.

\section{Discussion}

In the study, we demonstrated that age has an important prognostic value in patients with stage I adenocarcinoma regardless of other clinical variables: gender, smoking habit, comorbidity, type of histology, tumor size and lymphatic or blood vessel invasion. Therefore, 
A

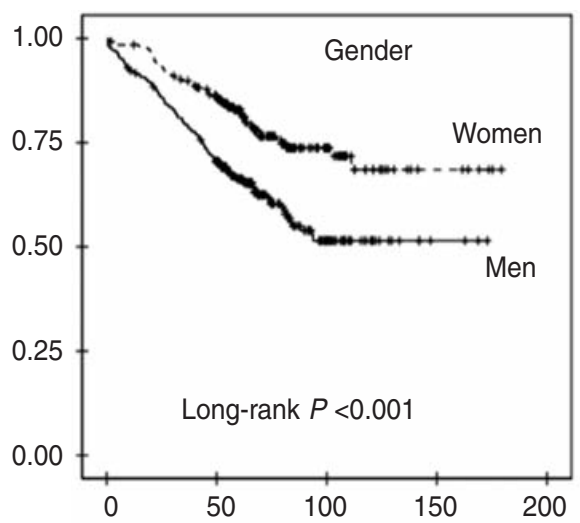

B

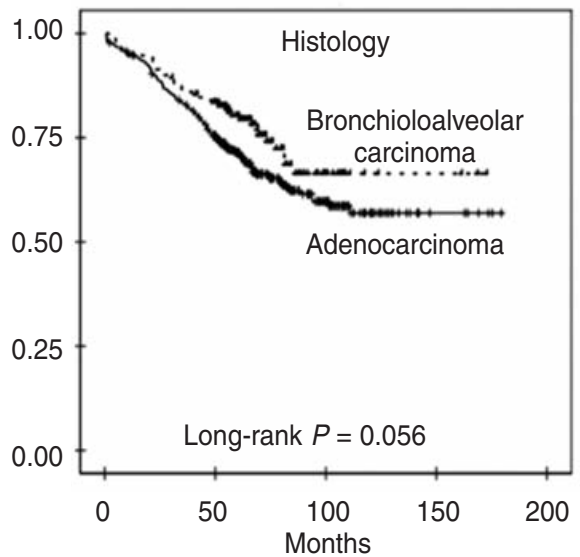

C

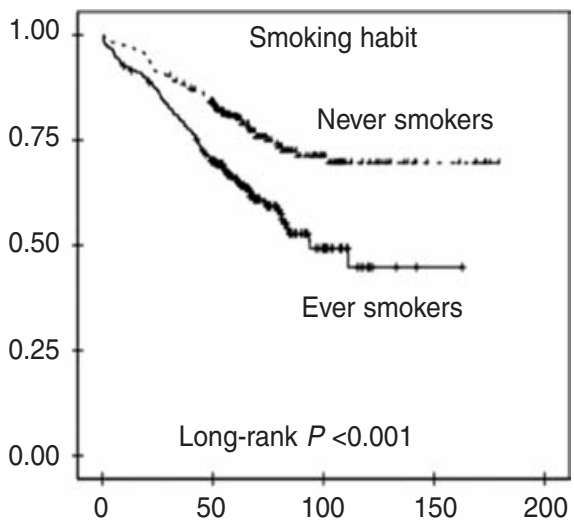

D

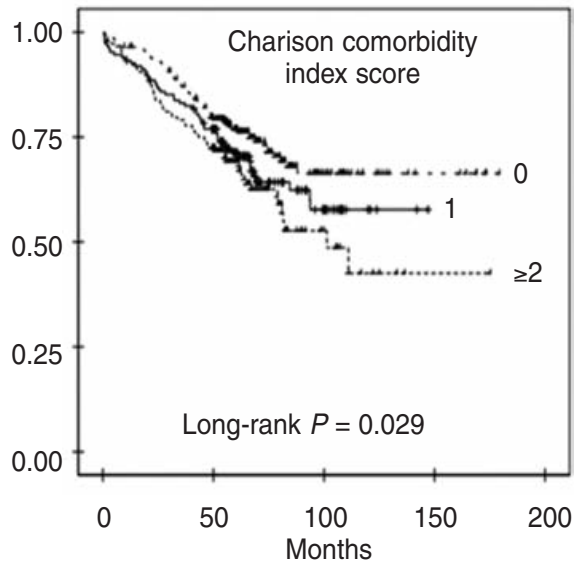

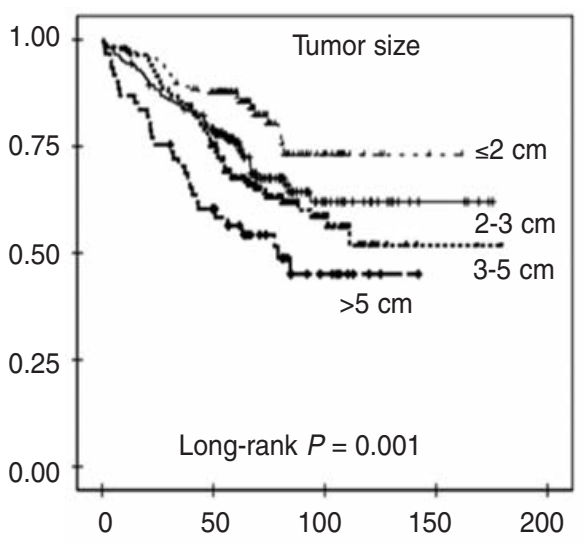
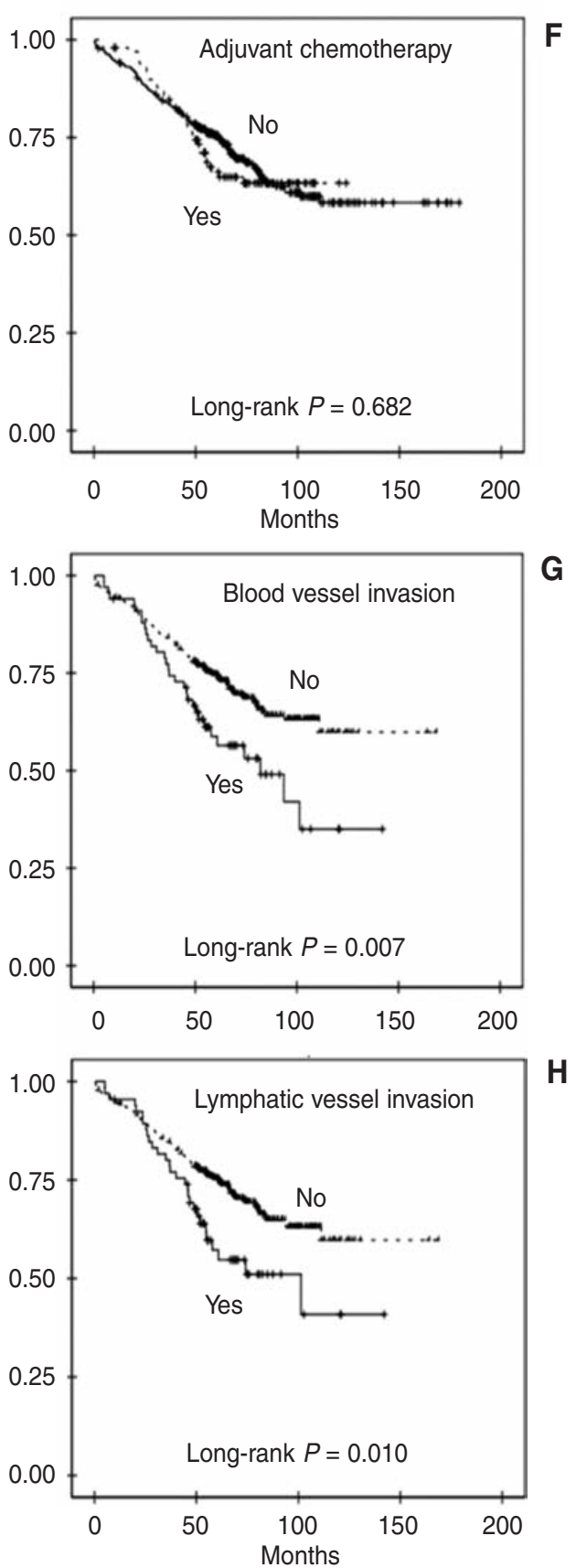

Figure 2 - Kaplan-Meier survival estimates for overall survival according to clinical variables: (A) gender, (B) histology, (C) smoking habit, (D) Charlson comorbidity index score, (E) tumor size, (F) adjuvant chemotherapy, (G) blood vessel invasion, (H) lymphatic vessel invasion. 
Table 2 - Adjusted hazards ratios being affected by risk factors in patients with pathologic stage I adenocarcinoma

\begin{tabular}{|c|c|c|c|c|}
\hline Variable & & Adjusted $\mathrm{HR}^{\mathrm{a}}$ & $95 \% \mathrm{Cl}$ & $P$ \\
\hline Age (yr) & $\begin{array}{l}<55 \\
55-61 \\
62-67 \\
\geq 68\end{array}$ & $\begin{array}{l}1.145 \\
1.251 \\
2.735\end{array}$ & $\begin{array}{l}\text { Reference } \\
0.629-2.084 \\
0.710-2.205 \\
1.623-4.608\end{array}$ & $\begin{array}{r}0.658 \\
0.438 \\
<0.001\end{array}$ \\
\hline Gender & $\begin{array}{l}\text { Women } \\
\text { Men }\end{array}$ & 1.605 & $\begin{array}{l}\text { Reference } \\
1.014-2.539\end{array}$ & 0.043 \\
\hline Smoking habit & $\begin{array}{l}\text { Never } \\
\text { Ever }\end{array}$ & 1.179 & $\begin{array}{l}\text { Reference } \\
0.760-1.829\end{array}$ & 0.462 \\
\hline CCIS & $\begin{array}{l}0 \\
1 \\
\geq 2\end{array}$ & $\begin{array}{l}0.975 \\
1.215\end{array}$ & $\begin{array}{l}\text { Reference } \\
0.646-1.472 \\
0.807-1.829\end{array}$ & $\begin{array}{l}0.904 \\
0.350\end{array}$ \\
\hline Histology & $\begin{array}{l}A D C \\
B A C\end{array}$ & 1.107 & $\begin{array}{l}\text { Reference } \\
0.744-1.645\end{array}$ & 0.616 \\
\hline Tumor, cm & $\begin{array}{l}\leq 2 \\
>2 \text { to } \leq 3 \\
>3 \text { to } \leq 5 \\
>5\end{array}$ & $\begin{array}{l}1.578 \\
1.580 \\
2.813\end{array}$ & $\begin{array}{l}\text { Reference } \\
0.918-2.712 \\
0.924-2.702 \\
1.531-5.168\end{array}$ & $\begin{array}{l}0.099 \\
0.094 \\
0.001\end{array}$ \\
\hline $\begin{array}{l}\text { Lymphatic vessel } \\
\text { invasion }\end{array}$ & $\begin{array}{l}\text { No } \\
\text { Yes }\end{array}$ & 2.399 & $\begin{array}{l}\text { Reference } \\
0.864-6.662\end{array}$ & 0.093 \\
\hline $\begin{array}{l}\text { Blood vessel } \\
\text { invasion }\end{array}$ & $\begin{array}{l}\text { No } \\
\text { Yes }\end{array}$ & 1.344 & $\begin{array}{l}\text { Reference } \\
0.486-3.720\end{array}$ & 0.569 \\
\hline $\begin{array}{l}\text { Adjuvant } \\
\text { chemotherapy }\end{array}$ & $\begin{array}{l}\text { No } \\
\text { Yes }\end{array}$ & 1.274 & $\begin{array}{l}\text { Reference } \\
0.805-2.018\end{array}$ & 0.302 \\
\hline
\end{tabular}

CCIS, Charlson comorbidity index score; ADC, adenocarcinoma; BAC, bronchioloalveolar carcinoma.

aHazard ratio after the adjustment for the other clinical variables in the Cox proportional hazards model.

age should be considered in classifying the patients into groups of higher or lower risk of death as well as in designing clinical trials.

In the study, the results of the Cox proportional hazards model indicated that risk of death showed tendencies of increasing with age (quartile) as well as with tumor size, in line with the T descriptor of the currently recommended staging system proposed by the International Association for the Study of Lung Cancer ${ }^{2}$.

Effect of age on survival of stage I NSCLC patients has been reported with inconsistent results. In a report by Bryant et al. ${ }^{7}$, younger age ( $<45$ years old) was associated with a poor survival compared with older patients. However, their population consisted of groups heterogenous in stage and histology, and the effect of age on overall survival disappeared in multiple analysis. Moreover, there has been no criterion of defining younger and older in terms of biologic age as well as considering carcinogenesis of lung cancer. Therefore, it is not reasonable that age is considered as a dichotomous variable with a specific cutoff value for age instead of a continuous one or a categorical variable by classifying into three or four classes as done in the present study. Shoji et al. ${ }^{9}$ reported that blood vessel invasion was a significant prognostic factor whereas age did not affect survival of the patients with stage IA NSCLC.
In contrast, Fujisawa et al. ${ }^{18}$ demonstrated that age and smoking habit were independent prognostic factors after adjustment for gender, type of histology, tumor differentiation and tumor size in patients with stage I NSCLC. Using the Surveillance, Epidemiology, and End Results (SEER) data base, Subramanian et al. ${ }^{8}$ recently conducted multiple analyses on survival of NSCLC patients and showed that the risk of death increases with age, but they did not evaluate the effect of important confounders like smoking habit and comorbidity because of limitations of the SEER database.

As expected, the highest quartile of age (eldest group) showed a tendency of being men, ever smoker, higher CCIS, and low probability of taking adjuvant chemotherapy in the present study. These clinical variables may have potential interactions with age as confounders. Except for adjuvant chemotherapy whose benefit in stage I NSCLC patients is still a controversial issue, these clinical characteristics were deemed to have an effect on survival of the patients. All of these clinical variables should be taken into account in the development of a more robust prognostic model. Therefore, we evaluated the prognostic relevance of these clinical variables, which was taken into account in multiple Cox proportional hazards regression analysis.

In addition to differences in clinical characteristics as age increases, Mostertz et al. ${ }^{4}$ recently noted different patterns of gene expression between younger and older NSCLC patients, where age was a determinant of overall survival of the patients. Therefore, we believe that differences in these clinical and biologic phenotypes between younger and older patients are plausible reasons for a prognostic significance of age.

The study has several limitations because it was conducted by retrospective analysis of the patients treated at 11 university hospitals, and bias could be present. Furthermore, overall survival, but not lung cancer-specific survival, was evaluated in the study. Overall survival could be affected by and overestimated because of the presence of comorbidities, particularly smoking-related disease, in patients with lung cancer. Nevertheless, we believed this possibility can be decreased by limiting the study to the patients with adenocarcinoma and investigating CCIS and smoking habit and taking them into account in multiple Cox proportional hazards regression analysis of the study.

\section{References}

1. Jemal A, Siegel R, Ward E, Hao Y, Xu J, Thun MJ: Cancer statistics, 2009. CA Cancer J Clin, 59: 225-249, 2009.

2. Goldstraw P, Crowley J, Chansky K, Giroux DJ, Groome PA, Rami-Porta R, Postmus PE, Rusch V, Sobin L: The IASLC Lung Cancer Staging Project: Proposals for the revision of the tnm stage groupings in the forthcoming (seventh) edition of the TNM classification of malignant tumours. J Thorac Oncol, 2: 706-714, 2007. 
3. Pignon JP, Tribodet H, Scagliotti GV, Douillard JY, Shepherd FA, Stephens RJ, Dunant A, Torri V, Rosell R, Seymour L, Spiro SG, Rolland E, Fossati R, Aubert D, Ding K, Waller D, Le Chevalier T: Lung adjuvant cisplatin evaluation: A pooled analysis by the lace collaborative group. J Clin Oncol, 26: 3552-3559, 2008.

4. Mostertz W, Stevenson M, Acharya C, Chan I, Walters K, Lamlertthon W, Barry W, Crawford J, Nevins J, Potti A: Ageand sex-specific genomic profiles in non-small cell lung cancer. JAMA, 303: 535-543, 2010.

5. Asmis TR, Ding K, Seymour L, Shepherd FA, Leighl NB, Winton TL, Whitehead M, Spaans JN, Graham BC, Goss GD: Age and comorbidity as independent prognostic factors in the treatment of non small-cell lung cancer: A review of National Cancer Institute of Canada Clinical Trials Group Trials. J Clin Oncol, 26: 54-59, 2008.

6. el-Torky M, el-Zeky F, Hall JC: Significant changes in the distribution of histologic types of lung cancer. A review of 4928 cases. Cancer, 65: 2361-2367, 1990.

7. Bryant AS, Cerfolio RJ: Differences in outcomes between younger and older patients with non-small cell lung cancer. Ann Thorac Surg, 85: 1735-1739, 2008.

8. Subramanian J, Morgensztern D, Goodgame B, Baggstrom MQ, Gao F, Piccirillo J, Govindan R: Distinctive characteristics of non-small cell lung cancer (NSCLC) in the young: A surveillance, epidemiology, and end results (SEER) analysis. J Thorac Oncol, 5: 23-28, 2010.

9. Shoji F, Haro A, Yoshida T, Ito K, Morodomi Y, Yano T, Maehara Y: Prognostic significance of intratumoral blood vessel invasion in pathologic stage IA non-small cell lung cancer. Ann Thorac Surg, 89: 864-869, 2010.

10. Battafarano RJ, Piccirillo JF, Meyers BF, Hsu HS, Guthrie TJ, Cooper JD, Patterson GA: Impact of comorbidity on sur- vival after surgical resection in patients with stage I nonsmall cell lung cancer. J Thorac Cardiovasc Surg, 123: 280287, 2002.

11. Yoshino I, Kawano D, Oba T, Yamazaki K, Kometani T, Maehara Y: Smoking status as a prognostic factor in patients with stage i pulmonary adenocarcinoma. Ann Thorac Surg, 81: 1189-1193, 2006.

12. Sekine I, Nishiwaki Y, Yokose T, Nagai K, Suzuki K, Kodama $\mathrm{T}$ : Young lung cancer patients in japan: Different characteristics between the sexes. Ann Thorac Surg, 67: 14511455, 1999.

13. Ost D, Goldberg J, Rolnitzky L, Rom WN: Survival after surgery in stage IA and IB non-small cell lung cancer. Am J Respir Crit Care Med, 177: 516-523, 2008.

14. Nordquist LT, Simon GR, Cantor A, Alberts WM, Bepler G: Improved survival in never-smokers vs current smokers with primary adenocarcinoma of the lung. Chest, 126: 347-351, 2004.

15. Toh CK, Gao F, Lim WT, Leong SS, Fong KW, Yap SP, Hsu AA, Eng P, Koong HN, Thirugnanam A, Tan EH: Never-smokers with lung cancer: Epidemiologic evidence of a distinct disease entity. J Clin Oncol, 24: 2245-2251, 2006.

16. Ryu JS, Han HS, Kim MJ, Kwak SM, Cho JH, Yoon YH, Lee HL, Chu YC, Kim KH: Immunohistochemical Detection of Lymph Nodes Micrometastases in Patients of Pathologic Stage I Non-small-cell Lung Cancer. Tuberc Respir Dis, 57: 345-350, 2004.

17. Mountain CF: Revisions in the international system for staging lung cancer. Chest, 111: 1710-1717, 1997.

18. Fujisawa T, Iizasa T, Saitoh Y, Sekine Y, Motohashi S, Yasukawa T, Shibuya K, Hiroshima K, Ohwada H: Smoking before surgery predicts poor long-term survival in patients with stage I non-small-cell lung carcinomas. J Clin Oncol, 17: 2086-2091, 1999. 